\title{
EPCAM wt Allele
}

National Cancer Institute

\section{Source}

National Cancer Institute. EPCAM wt Allele. NCI Thesaurus. Code C51229.

Human EPCAM wild-type allele is located within 2 p21 and is approximately $18 \mathrm{~kb}$ in length.

This allele, which encodes epithelial cell adhesion molecule protein, is involved in calciumindependent cellular adhesion. 